\title{
ARTICLE
}

\section{A 3.8-V earth-abundant sodium battery electrode}

\author{
Prabeer Barpanda ${ }^{1,2,3, \star}$, Gosuke Oyama ${ }^{1, \star}$, Shin-ichi Nishimura ${ }^{1,2}$, Sai-Cheong Chung ${ }^{1} \&$ Atsuo Yamada ${ }^{1,2}$
}

Rechargeable lithium batteries have ushered the wireless revolution over last two decades and are now matured to enable green automobiles. However, the growing concern on scarcity and large-scale applications of lithium resources have steered effort to realize sustainable sodium-ion batteries, $\mathrm{Na}$ and Fe being abundant and low-cost charge carrier and redox centre, respectively. However, their performance is limited owing to low operating voltage and sluggish kinetics. Here we report a hitherto-unknown material with entirely new composition and structure with the first alluaudite-type sulphate framework, $\mathrm{Na}_{2} \mathrm{Fe}_{2}\left(\mathrm{SO}_{4}\right)_{3}$, registering the highest-ever $\mathrm{Fe}^{3+} / \mathrm{Fe}^{2+}$ redox potential at $3.8 \mathrm{~V}$ (versus $\mathrm{Na}$, and hence $4.1 \mathrm{~V}$ versus $\mathrm{Li}$ ) along with fast rate kinetics. Rare-metal-free Na-ion rechargeable battery system compatible with the present Li-ion battery is now in realistic scope without sacrificing high energy density and high power, and paves way for discovery of new earth-abundant sustainable cathodes for large-scale batteries.

\footnotetext{
${ }^{1}$ Department of Chemical System Engineering, The University of Tokyo, 7-3-1 Hongo, Bunkyo-ku, Tokyo 113-8656, Japan. ${ }^{2}$ Unit of Element Strategy Initiative for Catalysts and Batteries, ESICB, Kyoto University, Kyoto 615-8510, Japan. ${ }^{3}$ Materials Research Center, Indian Institute of Science, Bangalore 560012, India. * These authors contributed equally to this work. Correspondence and requests for materials should be addressed to A.Y. (email: yamada@chemsys.t.u-tokyo.ac.jp).
} 
ithium (Li)-ion battery was intensely explored in 1980s leading to its commercialization in 1990s. Ever since, the synergistic effort in basic science and industrial optimization has led to the doubling of energy density. Currently, Li-ion batteries are ubiquitous in suites of small-scale consumer electronics, power tools as well as large-scale power sources driving the (plug-in) hybrid electric transportation and powergrid systems. The ever-growing global population and the meteoric rise in demand of easy access to modern technologies (gadgets/automobiles) have created multi-billion dollar battery industry. The current generation $\mathrm{Li}$-ion batteries use oxides (such as $\mathrm{LiCoO}_{2}$ and $\mathrm{LiMn}_{2} \mathrm{O}_{4}$ ) and olivine $\mathrm{LiFePO}_{4}$ as cathodes ${ }^{1-3}$. Suddenly, this manifold consumption of Li has led to its scarcity and price rise, with many raising a concern whether $\mathrm{Li}$ is the new gold that may trigger geo-political tension in future ${ }^{4}$. The vast range of battery applications can be divided into two broad categories: volume/weight-restricted applications such as electronics/automobiles and volume/weight-less-dependent uses such as remote area large power-grid systems for efficient use of electricity transmitted from thermal power plants and solar/wind mills. While the Li batteries are indispensable for former category, the later category has been economically catered in part by $\mathrm{Na}-\mathrm{S}$ batteries operating at high temperature over $300^{\circ} \mathrm{C}$. Resource optimization and tailor-made battery design for different applications, including dense smart grid with self-management housing system, is a global call, where Na-ion batteries operating at ambient temperatures can have vital role. Contrary to $\mathrm{Li}$, sodium $(\mathrm{Na})$ has abundant natural resources with even geographic distribution. Being the fifth most abundant element in earth's crust, $\mathrm{Na}$ charge carrier is also the second lightest alkali element in periodic table. In this context, mammoth effort has been geared to build efficient $\mathrm{Na}$-ion batteries with optimization of energy density, rate kinetics, low cost as well as safe and sustainable production and operation. In this pursuit, numerous Fe-based cathode compounds capable of efficient $\mathrm{Na}$ (de)insertion have been reported ${ }^{5-11}$.

Looking back to the history, soon after the conceptualization of intercalation reaction into $\mathrm{TiS}_{2}$ host in 1976 (ref. 12), research into Li-based and $\mathrm{Na}$-based insertion compounds kick-started in early 1980s $\left(\mathrm{Li}_{\mathrm{x}} \mathrm{CoO}_{2}\right.$ in 1980 (ref. 1) and $\mathrm{Na}_{\mathrm{x}} \mathrm{CoO}_{2}$ in 1981 (ref. 5)). However, the commercial prospects of light-weight Li-ion batteries in portable electronics steered massive effort on Li systems, resulting in a two-decade-long hibernation period for
$\mathrm{Na}$ counterparts. Over the past few years, the renewed interest on $\mathrm{Na}$-ion chemistry has seen extensive research on various $\mathrm{P} 2-$ and O3-type oxide-layered compounds and their solid solutions, mostly based on expensive transition metals such as Co and $\mathrm{Ni}$. The large-scale Na-batteries will be commercially viable with earth-abundant transition metal such as Fe. Till date, O3-type $\mathrm{NaFeO}_{2}$ (ref. 13) and P2-type $\mathrm{Na}_{\mathrm{x}}\left[\mathrm{Fe}_{1 / 2} \mathrm{Mn}_{1 / 2}\right] \mathrm{O}_{2}$ (ref. 7) are reported, both suffering from low operating potential even by using $\mathrm{Fe}^{4+} / \mathrm{Fe}^{3+}$ redox couple, and stable reversible capacity is limited. Using the inductive effect in polyanion framework systems, $\mathrm{Fe}^{3+} / \mathrm{Fe}^{2+}$ redox potential can be enhanced with full utilization of one-electron reaction ${ }^{14}$. In this pursuit, many $\sim 3 \mathrm{~V}$ Fe-based phosphate $\mathrm{PO}_{4}^{3-}$ insertion compounds have been reported. They are $\mathrm{Na}_{2} \mathrm{FePO}_{4} \mathrm{~F}$ (3.06 V; ref. 8), $\mathrm{NaFePO}_{4}(2.7 \mathrm{~V}$; ref. 9), $\mathrm{Na}_{2} \mathrm{FeP}_{2} \mathrm{O}_{7}\left(3 \mathrm{~V}\right.$; ref. 10) and $\mathrm{Na}_{4} \mathrm{Fe}_{3}\left(\mathrm{PO}_{4}\right)_{2}\left(\mathrm{P}_{2} \mathrm{O}_{7}\right)(3.2 \mathrm{~V}$; ref. 11). Newer Fe-based compounds with higher electrode potential can be realized by replacing phosphate $\mathrm{PO}_{4}^{3-}$ with sulphate $\mathrm{SO}_{4}^{2-}$ units taking advantage of their higher electronegativity ${ }^{14}$. This avenue is not yet realized with the only known $\mathrm{SO}_{4}^{2-}$-based compounds $\mathrm{NaFeSO}_{4} \mathrm{~F}$ and $\mathrm{NaFeSO}_{4} \mathrm{~F} \cdot 2 \mathrm{H}_{2} \mathrm{O}$ being electrochemically inactive ${ }^{15,16}$. Herein, we report an entirely new class of cathode, $\mathrm{Na}_{2} \mathrm{Fe}_{2}\left(\mathrm{SO}_{4}\right)_{3}$, combining the unusually high $\mathrm{Fe}$ redox potential $\sim 3.8 \mathrm{~V}$ versus $\mathrm{Na}$ with excellent rate kinetics as well as good economy. It benchmarks the highest-ever $\mathrm{Fe}^{3+} / \mathrm{Fe}^{2+}$ redox potential by far observed among all known oxides and oxyanionic insertion materials for $\mathrm{Na}$-ion batteries.

\section{Results}

Materials synthesis and crystal structure. Unlike the oxides and various polyanions $\left(\mathrm{BO}_{3}^{3-}, \mathrm{PO}_{4}^{3-}\right.$ and $\left.\mathrm{SiO}_{4}^{4-}\right)$ compounds, the $\mathrm{SO}_{4}^{2-}$ containing systems are acutely prone to thermal decomposition above $\sim 400{ }^{\circ} \mathrm{C}$ (leading to $\mathrm{SO}_{2}$ gas evolution). In addition, inherent dissolution of $\mathrm{SO}_{4}^{2-}$ in water makes it unstable in aqueous media. It rules out conventional high-temperature solid-state and aqueous solution-based synthetic routes. Thus, we used low-temperature $\left(T_{\mathrm{r}} \leq 350^{\circ} \mathrm{C}\right)$ solid-state methods to obtain $\mathrm{Na}_{2} \mathrm{Fe}_{2}\left(\mathrm{SO}_{4}\right)_{3}$ target compound. The unknown crystal structure of this new cathode material was determined by synchrotron powder X-ray diffraction (XRD) (Fig. 1). Rietveld refinement and Mössbauer data (Fig. 1, inset) confirm trace amount of Fe(III) impurity phase(s). Mössbauer spectrum of the pristine material,

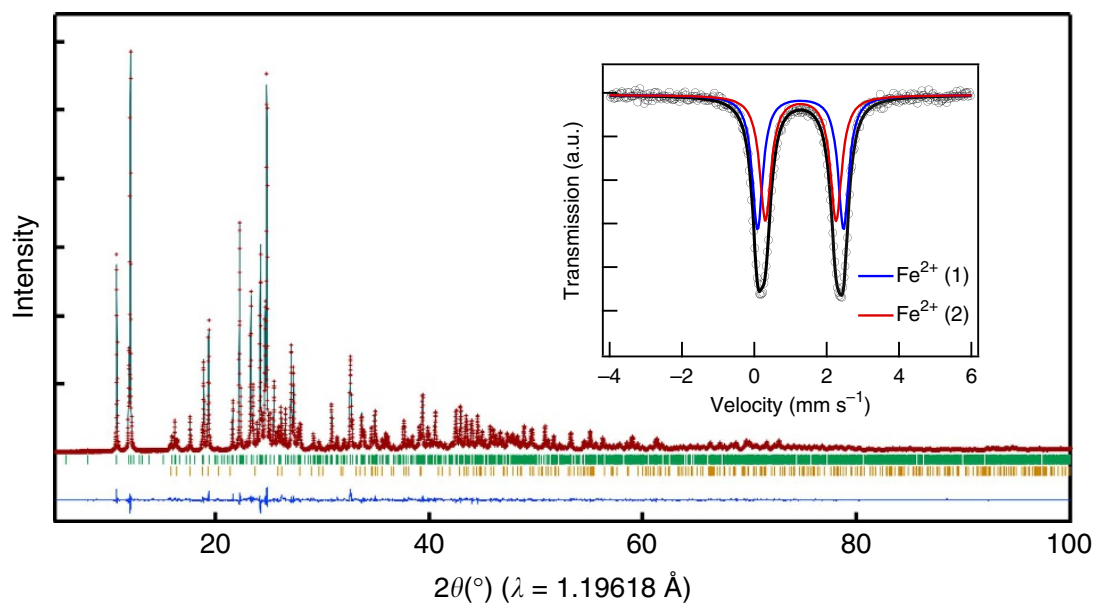

Figure 1 | XRD pattern of $\mathbf{N a}_{\mathbf{2}} \mathbf{F e}_{\mathbf{2}}\left(\mathbf{S O}_{\mathbf{4}}\right)_{\mathbf{3}}$. Rietveld refinement pattern of powder XRD data for $\mathrm{Na}_{2} \mathrm{Fe}_{2}\left(\mathrm{SO}_{4}\right)_{3}$. Experimental data and calculated profile and their difference are shown as red crosses and black and purple solid lines, respectively. The theoretical Bragg positions are shown with green ticks. Trace amount (about $4 \mathrm{wt} \%$ ) of bata- $\mathrm{FeSO}_{4}$ as an impurity was included in the analysis, as indicated by yellow ticks. (Inset) Room temperature Mössbauer spectrum of pristine $\mathrm{Na}_{2} \mathrm{Fe}_{2}\left(\mathrm{SO}_{4}\right)_{3}$ shows the existence of two distinctive $\mathrm{Fe}(\mathrm{II})$ sites in 1:1 ratio (red and blue lines). 
consisting only $\mathrm{Fe}$ (II) species, could be fitted with two doublets having 1:1 intensity ratio, which can be assigned to two distinct crystallographic sites, $\mathrm{Fe}(1)$ and $\mathrm{Fe}(2)$. All the Bragg reflections were indexed in a monoclinic lattice assuming $P 2_{1} / c$ (No. 14) symmetry with lattice parameters $a=11.46964(8) \AA$, $b=12.77002(9) \AA, \quad c=6.51179(5) \AA, \quad \beta=95.2742(4)^{\circ} \quad$ and $V=949.73(1) \AA^{3}$. Although non-stoichiometry was to be considered, the fitting was satisfactory $\left(R_{\mathrm{wp}}=4.87 \%, R_{\mathrm{p}}=3.94 \%\right.$, $R_{\text {Bragg }}=1.58 \%$ and Goodness of fit $\left.(\mathrm{GoF})=1.74\right)$. Trace amount (about $4 \mathrm{wt} \%$ ) of bata- $\mathrm{FeSO}_{4}$ as an impurity was included in the analysis. The crystallographic data are summarized in Supplementary Tables 1 and 2. Indexing and analysis adopting alternative $C 2 / c$ symmetry with one Fe site was also possible with slight increase in $R_{\text {Bragg }}$ as summarized in Supplementary Tables 3 and 4, indicating that local environments of two Fe sites are quite similar. Although $P 2_{1} / c$ symmetry seems more suitable in the present analysis, further systematic approach by electron diffraction and/or single-crystal XRD would be necessary for the firm conclusion on $\mathrm{P}_{1} / \mathrm{c}$ versus $\mathrm{C} 2 / \mathrm{c}$.

The refined crystal structure of $\mathrm{Na}_{2} \mathrm{Fe}_{2}\left(\mathrm{SO}_{4}\right)_{3}$ is shown in Fig. 2a. To the best of our knowledge, the composition and crystal structure of $\mathrm{Na}_{2} \mathrm{Fe}_{2}\left(\mathrm{SO}_{4}\right)_{3}$ are completely new and have never been reported in the literature. Deviating sharply from most of the $A_{\mathrm{x}} M_{2}\left(\mathrm{XO}_{4}\right)_{3}$-type compounds adopting the NASICONrelated structures, $\mathrm{Na}_{2} \mathrm{Fe}_{2}\left(\mathrm{SO}_{4}\right)_{3}$ does not contain the lantern units $\left[M_{2}\left(\mathrm{XO}_{4}\right)_{3}\right]$, forming a unique structure with alluauditetype framework. It would be convenient to denote $A A^{\prime} B M_{2}\left(X_{4}\right)_{3}$ as general alluaudite-type compounds, where $A=$ partially occupied $\mathrm{Na}(2), A^{\prime}=$ partially occupied $\mathrm{Na}(3), B=\mathrm{Na}(1), M=$ $\mathrm{Fe}^{2+}$ and $X=\mathrm{S}$ in the present case. To the best of our knowledge, this is the first sulphate compound with alluaudite-type framework. The Fe ions occupy octahedral sites that share edges with a crystallographically equivalent octahedron, forming $\mathrm{Fe}_{2} \mathrm{O}_{10}$ dimer units. These $\mathrm{Fe}$ ions were assigned to two distinct crystallographic sites, $\mathrm{Fe}(1)$ and $\mathrm{Fe}(2)$ (Fig. 2b). Even though the local structures of $\mathrm{Fe}(1)$ and $\mathrm{Fe}(2)$ are similar to each other, they are crystallographically distinct as revealed by two doublets in the Mössbauer spectrum (Fig. 1, inset). These isolated edge-sharing $\mathrm{Fe}_{2} \mathrm{O}_{10}$ dimers are in turn bridged together by $\mathrm{SO}_{4}$ units strictly by corner-sharing mode, hence forming a three-dimensional framework with large tunnels along $c$ axis. The constituent $\mathrm{Na}$ occupies three distinct crystallographic sites; one fully occupied and two partially occupied. This new structure type should open up an entirely new $\mathrm{Na}_{2}{ }_{-x} \mathrm{M}_{2}\left(\mathrm{SO}_{4}\right)_{3}(M=\mathrm{Mg}, \mathrm{Ti}, \mathrm{Mn}, \mathrm{Co}, \mathrm{Ni}, \mathrm{V}$ and VO) family of compounds as potential cathodes/anodes/solid electrolytes for further material exploration. Although $\mathrm{NaMn}$ $\mathrm{Fe}_{2}\left(\mathrm{PO}_{4}\right)_{3}$ compounds with alluaudite-type $A A^{\prime} B M_{2}\left(\mathrm{XO}_{4}\right)_{3}$ framework of $A, A^{\prime}=$ partially occupied $\mathrm{Na}, B=\mathrm{Mn}^{2+}$ and $\mathrm{Fe}^{2+}, \quad M=\mathrm{Mn}^{3+}$ and $\mathrm{Fe}^{3+}$ and $X=\mathrm{P}$ was previously synthesized $^{17}$, it showed weak electrochemical reactivity. Great advantage to use $\left(\mathrm{SO}_{4}\right)^{2-}$ instead of $\left(\mathrm{PO}_{4}\right)^{3-}$ is to stabilize the nearly $\mathrm{Na}-\mathrm{Fe}$ equi-amount $\mathrm{Na}_{2} \mathrm{Fe}_{2}\left(\mathrm{SO}_{4}\right)_{3}$ compound including only $\mathrm{Fe}^{2+}$ with partially occupied $\mathrm{Na}^{+}$sites suitable for fast $\mathrm{Na}^{+}$diffusion upon electrode reaction.

Electrochemical properties. The electrode properties of as-synthesized $\mathrm{Na}_{2} \mathrm{Fe}_{2}\left(\mathrm{SO}_{4}\right)_{3}$ were examined with no further optimization such as particle downsizing or carbon coating. The primary particle size was evaluated to be $\sim 100-200 \mathrm{~nm}$ by scanning electron microscope observation (Supplementary Fig. 1), and the electrode loading was $c a .3 \mathrm{mg} \mathrm{cm}^{-2}$. The corresponding voltage-capacity profiles for first few cycles between 2.0-4.5 V (versus $\left.\mathrm{Na} / \mathrm{Na}^{+}\right)$at a rate of $\mathrm{C} / 20\left(25^{\circ} \mathrm{C}\right.$ ) is shown in Fig. 3a. The $\mathrm{Na}_{2} \mathrm{Fe}_{2}\left(\mathrm{SO}_{4}\right)_{3}$ cathode offers an average potential of $3.8 \mathrm{~V}$ (versus $\mathrm{Na} / \mathrm{Na}^{+}$), which is the highest-ever $\mathrm{Fe}^{3+} / \mathrm{Fe}^{2+}$ redox potential in any materials environment. The well-known NASICON-type $\mathrm{Fe}(\mathrm{III})_{2}\left(\mathrm{SO}_{4}\right)_{3}$ (ref. 18) has same composition with desodiated $\mathrm{Na}_{2} \mathrm{Fe}_{2}\left(\mathrm{SO}_{4}\right)_{3}$ in the present study, but NASICON phase delivers an average potential of $3.3 \mathrm{~V}$ (versus $\mathrm{Na} / \mathrm{Na}^{+}$) upon $\mathrm{Na}$ insertion ${ }^{19}$.

Thereby, $\mathrm{Na}_{2} \mathrm{Fe}_{2}\left(\mathrm{SO}_{4}\right)_{3}$ cathode is characterized by three distinctive features: (i) totally new pristine composition with structure with edge-sharing $\mathrm{FeO}_{6}$ octahedra different from NASICON- or NASICON-like phases with corner-sharing $\mathrm{FeO}_{6}$ octahedra; (ii) initial valence state is $\mathrm{Fe}(\mathrm{II})$ with inherent existence of $\mathrm{Na}$ in the structure allowing to function as a cathode of $\mathrm{Na}$ - 'ion' battery system; and (iii) much higher electrode potential by $\sim 0.5 \mathrm{~V}$ comparing to the NASICON phases, providing very suitable operating potential of $3.8 \mathrm{~V}$ (versus $\mathrm{Na} / \mathrm{Na}^{+}$) with smooth sloppy charge-discharge profiles over a narrow voltage range in 3.3-4.3 V window. Features (i) and (ii) account for the abnormally high potential of $\mathrm{Na}_{2} \mathrm{Fe}_{2}\left(\mathrm{SO}_{4}\right)_{3}$ (ref. 20). The voltage $E$ can be expressed as $E=\Delta G^{\circ} / n F=\left(x G^{\circ}{ }_{\mathrm{Na}}+G^{\circ}\right.$ Host $\left.-G^{\circ}{ }_{\text {NaxHost }}\right) / n F$, where $n, F$ and $G$ are number of electrons, Faraday constant and Gibbs free energy, respectively. For $\mathrm{Na}_{2} \mathrm{Fe}_{2}\left(\mathrm{SO}_{4}\right)_{3}$, the difference $G_{\text {Host }}^{\circ}-G_{\text {NaxHost }}^{\circ}$ is large since the sodiated state is synthesized as stable state (low $G^{\circ}{ }_{\text {NaxHost }}$ ),

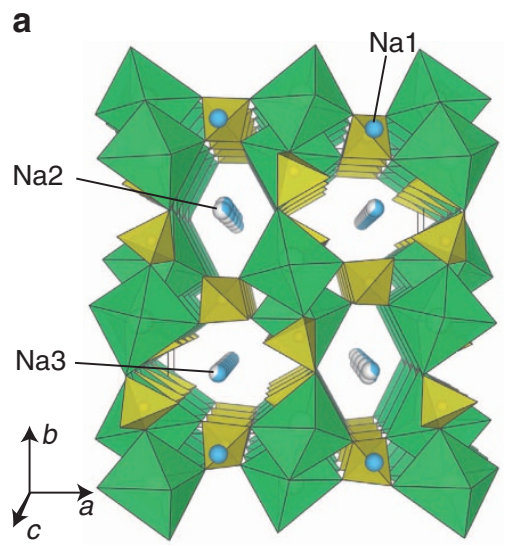

b
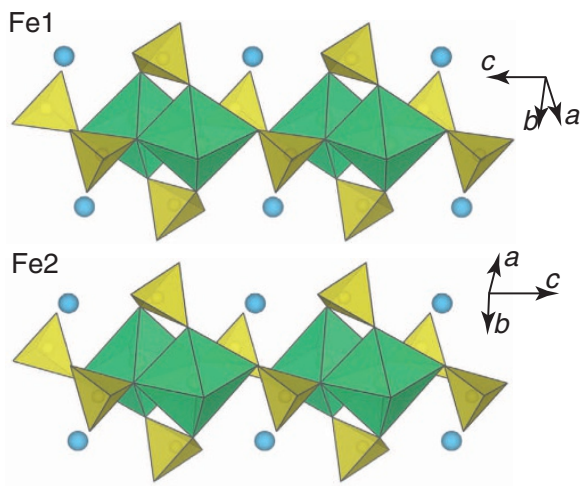

Figure 2 | Crystal structure of $\mathbf{N a}_{\mathbf{2}} \mathbf{F e}_{\mathbf{2}}\left(\mathbf{S O}_{\mathbf{4}}\right)_{\mathbf{3}}$. (a) The structure of $\mathrm{Na}_{2} \mathrm{Fe}_{2}\left(\mathrm{SO}_{4}\right)_{3}$ projected along the $c$ axis; and (b) local environment of two independent Fe sites. Green octahedra, yellow tetrahedra and blue spheres show $\mathrm{FeO}_{6}, \mathrm{SO}_{4}$ and $\mathrm{Na}$, respectively. Fe ions occupy two kinds of crystallographic sites that have distinctive octahedral geometries. Each $\mathrm{FeO}_{6}$ octahedra share an edge with the crystallographically equivalent octahedra and form Fe $\mathrm{O}_{10}$ dimers. The $\mathrm{SO}_{4}^{2-}$ anions interconnect these dimers so as to build up a three-dimensional framework structure. 
a

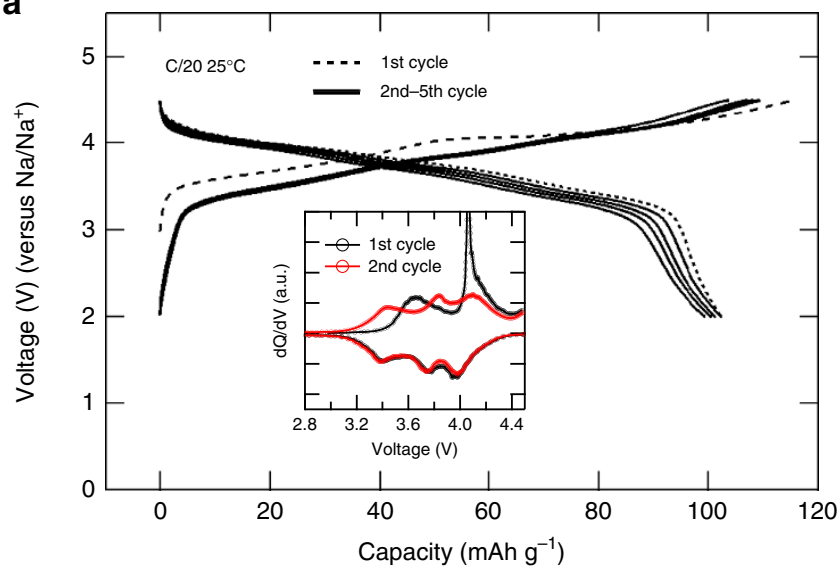

b

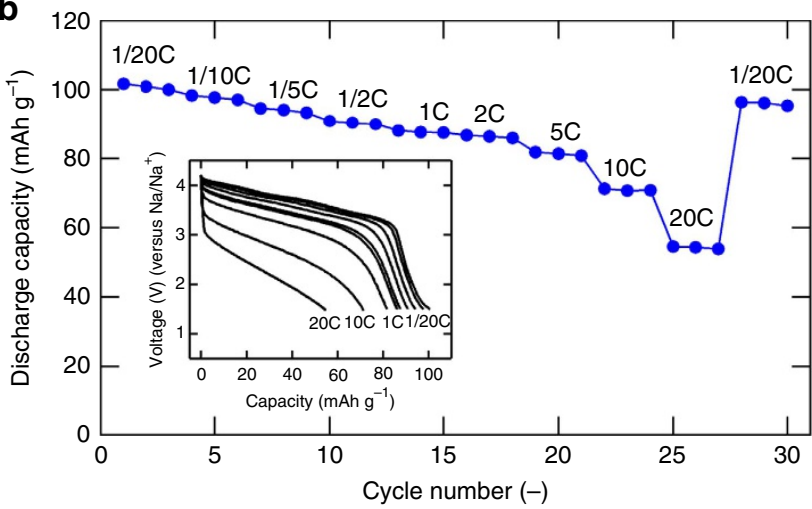

Figure 3 | Electrode properties of $\mathrm{Na}_{2}{ }_{-} \mathrm{Fe}_{2}\left(\mathrm{SO}_{4}\right)_{3}$ in $\mathrm{Na}$ cell.

(a) Galvanostatic charging and discharging profiles of $\mathrm{Na}_{2-x} \mathrm{Fe}_{2}\left(\mathrm{SO}_{4}\right)_{3}$ cathode cycled between 2.0 and $4.5 \mathrm{~V}$ at a rate of $\mathrm{C} / 20(2 \mathrm{Na}$ in $20 \mathrm{~h}$ ) at $25^{\circ} \mathrm{C}$. First (1st) cycle is shown in dashed black line, and 2 nd-5th cycle in solid black lines. (Inset) The differential galvanostatic profiles (dQ/dV) of $\mathrm{Na}_{2-x} \mathrm{Fe}_{2}\left(\mathrm{SO}_{4}\right)_{3}$ cathode showing two distinctive peaks during the first charge and broader three peaks upon subsequent discharging/charging processes. (b) Capacity retention upon cycling up to 30 cycles under various rate of $\mathrm{C} / 20$ ( $2 \mathrm{Na}$ in $20 \mathrm{~h}$ ) to $20 \mathrm{C}$ (2 Na in $3 \mathrm{~min}$ ). (Inset) The discharge curves of $\mathrm{Na}_{2}{ }_{x} \mathrm{Fe}_{2}\left(\mathrm{SO}_{4}\right)_{3}$ as a function of rate (from $\mathrm{C} / 20$ to 20C). Before each discharge, the cells were charged at $\mathrm{C} / 10$ to $4.2 \mathrm{~V}$.

whereas the desodiated one is electrochemical-generated (possibly metastable) state (high $G_{\text {Host }}^{\circ}$ ). This is reverse for NASICONtype $\mathrm{Fe}_{2}\left(\mathrm{SO}_{4}\right)_{3}$ and any related $\mathrm{Fe}(\mathrm{III})$ cathodes. Another factor, the edge-sharing geometry of the $\mathrm{Fe}$ octahedra in $\mathrm{Na}_{2} \mathrm{Fe}_{2}\left(\mathrm{SO}_{4}\right)_{3}$, will push up $G^{\circ}$ Host owing to the strong $\mathrm{Fe}^{3+}-\mathrm{Fe}^{3+}$ repulsion, leading to high $E^{19}$. This geometric characteristics can be found in other high-voltage materials such as triplite-type $\mathrm{LiFeSO}_{4} \mathrm{~F}$ (ref. 21), and $\mathrm{Li}_{2} \mathrm{FeP}_{2} \mathrm{O}_{7}$ (ref. 22). In fact, $\mathrm{Na}_{2} \mathrm{Fe}_{2}\left(\mathrm{SO}_{4}\right)_{3}$ has the shortest $\mathrm{Fe}-\mathrm{Fe}$ distance among these materials. Thus, the operating potential of $3.8 \mathrm{~V}$ by $\mathrm{Na}_{2}{ }_{x} \mathrm{Fe}_{2}\left(\mathrm{SO}_{4}\right)_{3}$ (that is, $4.1 \mathrm{~V}$ versus $\mathrm{Li}$ ) records the highest value among all $\mathrm{Fe}$-based battery cathodes; it is even higher than those of $\mathrm{Fe}^{4+} / \mathrm{Fe}^{3+}$ redox couple in simple oxides as $\mathrm{Na}_{1-} \mathrm{FeO}_{2}$ (Fig. 5). Surprisingly, it exceeds the highest record in $\mathrm{Li}$ system in $\mathrm{Li}_{1}{ }_{\mathrm{x}} \mathrm{FeSO}_{4} \mathrm{~F}, \mathrm{Li}_{2} \mathrm{FeP}_{2} \mathrm{O}_{7}$ and $\mathrm{Li}_{2} \mathrm{Fe}\left(\mathrm{SO}_{4}\right)_{2}(\sim 3.9 \mathrm{~V} \text { versus } \mathrm{Li} \text { and hence } 3.6 \mathrm{~V} \text { versus } \mathrm{Na})^{21-24}$. Unlike the fluorosulphate cathodes, this high redox voltage is obtained without using electronegative $\mathrm{F}^{-}$units that make the synthesis cumbersome and enhances hygroscopic/instability in the final cathodes.

The initial reversible capacity of $102 \mathrm{mAhg}^{-1}$, which corresponds to $85 \%$ of one-electron theoretical capacity (ca. $120 \mathrm{mAh} \mathrm{g}^{-1}$ ) based on $\mathrm{Fe}^{3+} / \mathrm{Fe}^{2+}$ redox couple, was highly reversible over 30 cycles under various current rate (Fig. 3b). Irreversible capacity of $<14 \mathrm{mAhg}^{-1}$ ( $>88 \%$ charge-discharge efficiency) in Fig. 3a may come from electrolyte decomposition as the cell was charged up to very high voltage, $4.5 \mathrm{~V}$ versus $\mathrm{Na}(4.8 \mathrm{~V}$ versus $\mathrm{Li}$ ). When the current is further increased, $86 \%$ (versus the value at $\mathrm{C} / 20$ ) of the initial capacity can be delivered in $1 \mathrm{~h}(1 \mathrm{C})$, $85 \%$ in $30 \mathrm{~min}(2 \mathrm{C})$ and $70 \%$ in $6 \mathrm{~min}(10 \mathrm{C})$ as shown in Fig. $3 \mathrm{~b}$. This high-rate capability of $\mathrm{Na}_{2}{ }_{x} \mathrm{Fe}_{2}\left(\mathrm{SO}_{4}\right)_{3}$ electrode suggests that Na-ion migration in the framework structure is fast, as will be discussed in the later section.

Reaction mechanisms. In spite of its high power operation and excellent cyclability, the voltage profile of the initial charge was slightly different from those of the subsequent cycles. During the first charge segment, the average redox reaction occurs at $3.9 \mathrm{~V}$ (versus $\mathrm{Na}$ ), which drops to $3.8 \mathrm{~V}$ in subsequent cycles. The differential galvanostatic profiles $(\mathrm{dQ} / \mathrm{d} V)$ of $\mathrm{Na}_{2}{ }_{x} \mathrm{Fe}_{2}\left(\mathrm{SO}_{4}\right)_{3}$ cathode (inset of Fig. 3a) showing two distinctive peaks (3.65 and $4.06 \mathrm{~V}$ versus $\mathrm{Na} / \mathrm{Na}^{+}$) at the first charge and broader three peaks $(3.42,3.80$, and $4.04 \mathrm{~V}$ in the middle points versus $\mathrm{Na} / \mathrm{Na}^{+}$) upon subsequent discharging/charging processes. These indicate the occurrence of some irreversible structural transformation during first desodiation process, similar to the cases of $\mathrm{Li}_{2} \mathrm{FeSiO}_{4}$ and $\mathrm{Li}_{2} \mathrm{FeP}_{2} \mathrm{O}_{7}$ (ref. 22). The sloping voltage curve over the entire range of $\mathrm{Na}$ composition suggests a singlephase homogeneous reaction mechanism involving minimal volume change. This hypothesis was verified by comparative XRD patterns and Mossbauer Spectra of the $\mathrm{Na}_{2}{ }_{x} \mathrm{Fe}_{2}\left(\mathrm{SO}_{4}\right)_{3}$ $(x=0-1.6)$ compositions prepared by chemical oxidation (Supplementary Fig. 2 and Supplementary Table 5), as well as by in situ XRD measurement during electrochemical chargedischarge (Supplementary Fig. 3). Continuous shift of diffraction peaks with mere volume change $(\Delta V)$ of $-1.6 \%$ was confirmed, and in striking contrast to the $\mathrm{Li}_{\mathrm{x}} \mathrm{FePO}_{4}$ system dominated by the two-phase separation ${ }^{25}$. This is beneficial for long-term cycling, uniform reaction over the whole electrode and longevity of the cathode involving less aggressive electromechanical grinding during its operation ${ }^{26}$. Such a small volume change in chargedischarge reaction may give another explanation for the high-rate capability but is quite surprising, considering much larger ionic radius of $\mathrm{Na}^{+}$than that of $\mathrm{Li}^{+}$. Indeed, the $\Delta V=-17.6 \%$ in $\mathrm{Na}_{x} \mathrm{FePO}_{4}$ has been reported to be much larger than $\Delta V=$ - 6.9\% in $\mathrm{Li}_{x} \mathrm{FePO}_{4}$ (refs 9,27).

Na-ion dynamics. $\mathrm{Na}_{2} \mathrm{Fe}_{2}\left(\mathrm{SO}_{4}\right)_{3}$ turns out to be an ideal host structure for efficient and fast $\mathrm{Na}^{+}$(de)insertion with unusually high Fe redox potential. To gain further insight on this suitable structure, bond valence (BV) method was used to evaluate the validity of the crystal structure as well as to elucidate possible $\mathrm{Na}$ diffusion paths by utilizing the soft-BV parameters ${ }^{28,29}$. Difference of the $\mathrm{BV}$ sum from the ideal value $(\triangle B V S)$ provides a simple measure of positional suitability of mobile ions in solid frameworks ${ }^{30}$. Figure 4 shows a map of $\triangle B V S$ as equi-value surface. Inner side of the equi-value surface shows accessible spaces for $\mathrm{Na}^{+}$in the $\left[\mathrm{Fe}_{2}\left(\mathrm{SO}_{4}\right)_{3}\right]^{2-}$ framework. All the refined Na positions are consistent with the $\triangle B V S$ map where the maximum $\triangle B V S$ at $\mathrm{Na}$ positions are $<0.2$. Although the $\mathrm{Na} 1$ and the $\mathrm{Na} 2$ looks to have rather localized character in the present analysis, the Na3 site are clearly permeating along the [001] direction.

$A b$ initio calculations were performed to gain more quantitative understandings. The calculations were conducted for the $\mathrm{Na}$ poor region (see Methods section for details). At this concentration, we found that the binding energy of $\mathrm{Na}$ to the $\mathrm{Na} 2$ site is most favourable and to the $\mathrm{Na} 3$ least favourable. The activation 
a

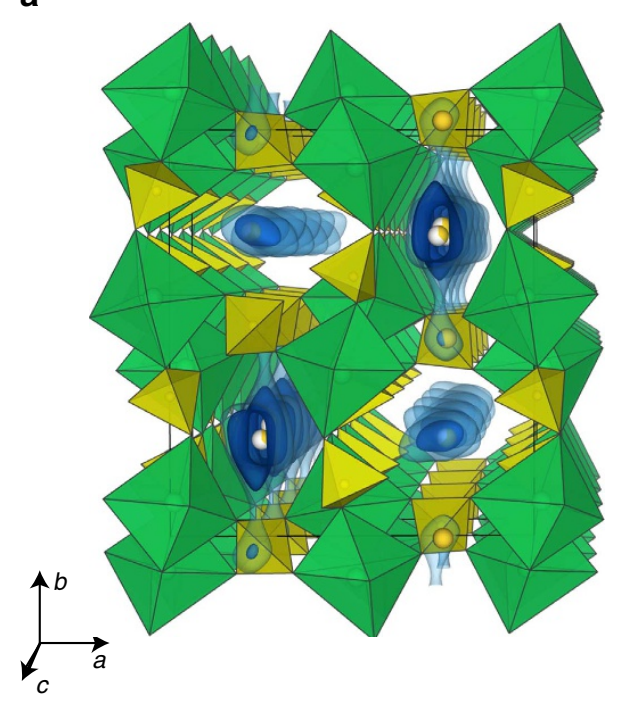

b

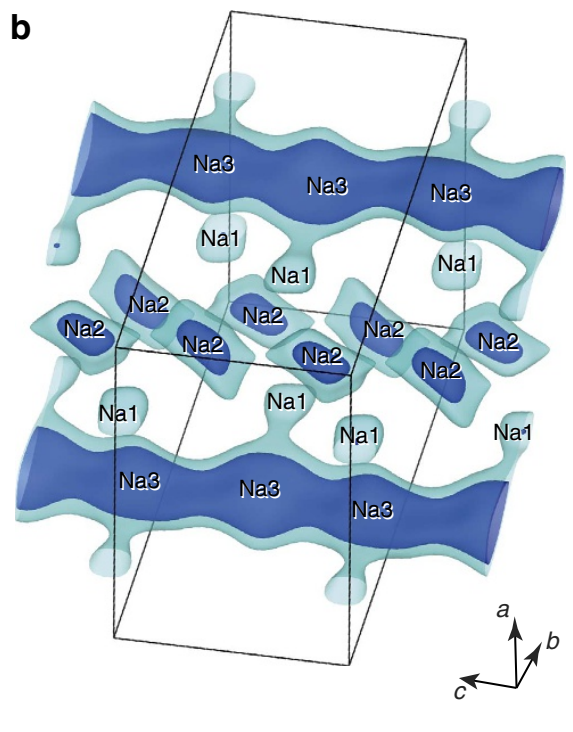

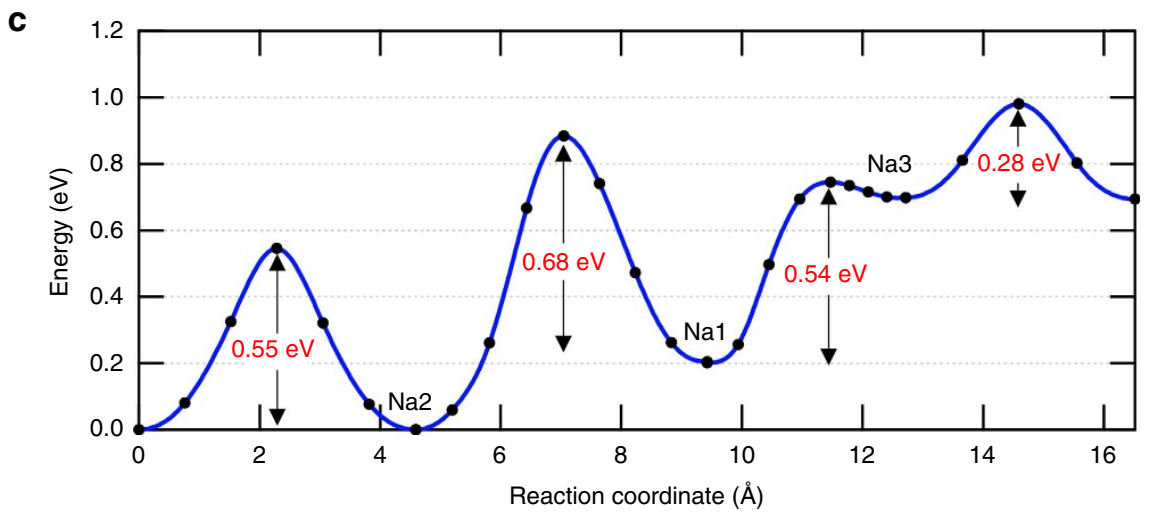

Figure 4 | $\mathbf{N a}$-ion diffusion in $\mathbf{N a}_{\mathbf{2}} \mathbf{F e}_{\mathbf{2}}\left(\mathbf{S O}_{\mathbf{4}}\right)_{\mathbf{3}}$. (a,b) Equi-value surface of the $\triangle B V S$. The blue and light-blue surfaces are for $\Delta B V S=0.2$ and 0.4 , respectively. Inner side of the surface corresponds to accessible spaces for the $\mathrm{Na}$ ions. Green and yellow polyhedra are that of $\mathrm{FeO}_{6}$ and $\mathrm{SO}_{4}$, respectively. (c) Migration activation energy of $\mathrm{Na}^{+}$ion calculated with DFT. Shown are the values (from left to right) for migrations along the $\mathrm{c}$ axis for the Na2 sites, between $\mathrm{Na} 2$ and $\mathrm{Na} 1$ sites, between $\mathrm{Na} 1$ and $\mathrm{Na} 3$ sites, and along the $\mathrm{c}$ axis for the $\mathrm{Na} 3$ sites. Calculations are done at low concentration of $\mathrm{Na}$.

energies for the Na-ion migration within the Na3 channel indeed is found to be low, which is $0.28 \mathrm{eV}$. Liquid-like value of $0.14 \mathrm{eV}$ was calculated for defect diffusion along the channel and is among the lowest for Na-ion conductors ${ }^{31}$. The value for the $\mathrm{Na} 2$ channel is $0.54 \mathrm{eV}$ similar to that for $\mathrm{Na}_{2} \mathrm{FeP}_{2} \mathrm{O}_{7}$, which shows very fast charge-discharge kinetics ${ }^{10,32,33}$. For migrations between channels, the activation energies are 0.88 and $0.58 \mathrm{eV}$ for back-and-forth transport between $\mathrm{Na} 1$ and $\mathrm{Na} 2$ sites, and they are 0.54 and $0.05 \mathrm{eV}$ for that between $\mathrm{Na} 1$ and $\mathrm{Na3}$. We can therefore postulate that this material has one-dimensional $\mathrm{Na}^{+}$ conduction channels along the $c$ axis for both the $\mathrm{Na} 2$ and $\mathrm{Na} 3$ sites, while the $\mathrm{Na} 1$ ion can be extracted through the $\mathrm{Na} 3$ sites. As a result, all the $\mathrm{Na}$ ions are accessible for (de)intercalation reaction with no limitation towards theoretical capacity. In particular, the continuous space around $\mathrm{Na} 3$ site can act as a fast $\mathrm{Na}$ transport channel during the charge-discharge reaction, which can be the origin of excellent kinetics of $\mathrm{Na}_{2} \mathrm{Fe}_{2}\left(\mathrm{SO}_{4}\right)_{3}$ cathode material. Similar technical strategies applied for $\mathrm{Li}_{\mathrm{x}} \mathrm{FePO}_{4}$, which also shows one-dimensional diffusion ${ }^{34}$, should be effective to enhance electrode performance such as diminishing defect density and minimizing particle size along $c$ axis ${ }^{35}$.

Material stability. Finally, the material stability (chemical/ thermal/storage) was examined ${ }^{36}$. Similar to other sulphate-based cathodes (for example, fluorosulphates and bisulphates), $\mathrm{Na}_{2} \mathrm{Fe}_{2}\left(\mathrm{SO}_{4}\right)_{3}$ was found to dissolve completely in water. Thus, it is not stable in aqueous condition, a fact that was further verified by observation of its steady degradation upon long-time moisture exposure (in ambient condition) to form a hydrated derivative $\mathrm{Na}_{2} \mathrm{Fe}\left(\mathrm{SO}_{4}\right)_{2} \cdot 4 \mathrm{H}_{2} \mathrm{O}$. Nevertheless, with minimal exposure of freshly prepared sample to ambient air and careful packaging/storage (in inert atmosphere), this metastable compound remains intact with no deterioration in its electrochemical properties. Further, the thermal analysis of $\mathrm{Na}_{2} \mathrm{Fe}_{2}\left(\mathrm{SO}_{4}\right)_{3}$ noticed gradual weight loss upon heating above $450^{\circ} \mathrm{C}$ with simultaneous decomposition of $\mathrm{SO}_{4}$ units, release of $\mathrm{SO}_{2}$ gas and oxidation of $\mathrm{Fe}^{2+}$ species leading to the formation of $\mathrm{Na}_{2} \mathrm{SO}_{4}, \mathrm{Fe}_{2} \mathrm{O}_{3}$ and $\mathrm{Fe}_{3} \mathrm{O}_{4}$. In spite of this thermal decomposition above $450^{\circ} \mathrm{C}$, it should be noted that $\mathrm{Na}_{2} \mathrm{Fe}_{2}\left(\mathrm{SO}_{4}\right)_{3}$ compound offers sufficient thermal stability of real-life battery applications.

\section{Discussion}

Searching for novel low-cost cathode materials for rechargeable Na-ion batteries, we have synthesized a whole new family of cathode materials with general formula $\mathrm{Na}_{2} \mathrm{M}_{2}\left(\mathrm{SO}_{4}\right)_{3}$. The first such candidate, Fe-based $\mathrm{Na}_{2} \mathrm{Fe}_{2}\left(\mathrm{SO}_{4}\right)_{3}$, delivers a reversible capacity exceeding $100 \mathrm{mAhg}^{-1}$ with the working $\mathrm{Fe}^{3+} / \mathrm{Fe}^{2+}$ 


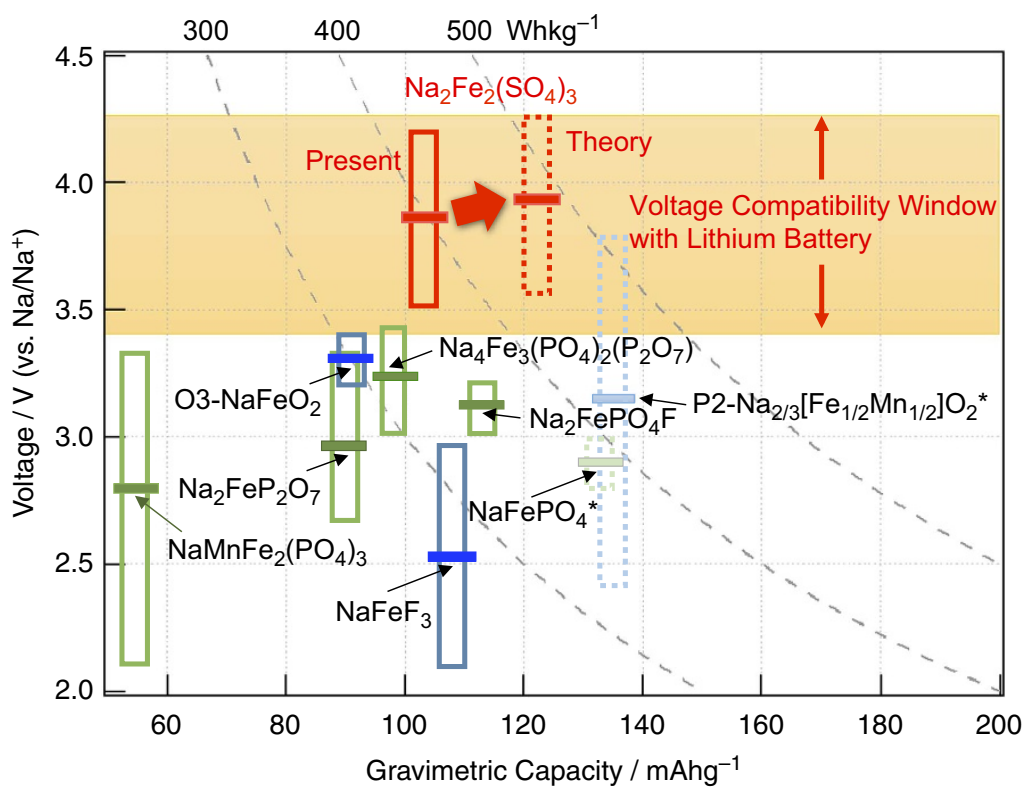

Figure 5 | Overall comparison of the Fe-based cathode materials that can function as Na sources in Na-ion battery system. Polyanionic cathode materials are shown as green boxes and simple oxides/fluorides as blue, respectively. Horizontal bars represent average voltage. Yellow band indicates voltage region that can ensure the compatibility with Li-ion batteries. The new compound $\mathrm{Na}_{2} \mathrm{Fe}_{2}\left(\mathrm{SO}_{4}\right)_{3}$ is presented by the red box together with its expected dashed-red region based on the theoretical capacity. ( ${ }^{\star}$ The capacity and voltage of $\mathrm{P} 2-\mathrm{Na}_{2 / 3-x}\left[\mathrm{Fe}_{1 / 2} \mathrm{Mn}_{1 / 2}\right] \mathrm{O}_{2}$ is assumed by $0<x<2 / 3$ region by inherent amount of $\mathrm{Na}$ with large hysteresis including both $\mathrm{Fe}^{4+} / \mathrm{Fe}^{3+}$ and $\mathrm{Mn}^{4+} / \mathrm{Mn}^{3+}$ redox reactions, as separately denoted with dashed pale blue box. Dashed pale green box for $\mathrm{NaFePO}_{4}$ indicate it cannot be directly synthesized and sluggish kinetics in electrode reaction.)

potential located at $3.8 \mathrm{~V}$ (versus $\mathrm{Na} / \mathrm{Na}^{+}$), the highest known value among all Fe-based insertion compounds. This abnormally high voltage is compatible with the thermodynamic limit of current generation organic electrolytes offering stable/safe operation. In addition, it offers excellent rate kinetics and cycling stability without demanding any additional cathode optimization. It forms an open framework host for efficient (de)intercalation of $\mathrm{Na}$ ions with very low activation energy. Operating voltage and reversible capacity of various known iron-based cathode for $\mathrm{Na}$-'ion' (cathode functions as whole $\mathrm{Na}$ source) battery system are summarized in Fig. 5. The new material $\mathrm{Na}_{2} \mathrm{Fe}_{2}\left(\mathrm{SO}_{4}\right)_{3}$ is benchmarking and worth further optimizing as it is the first Fe-based cathode for $\mathrm{Na}$ battery to offer high voltage compatible with $\mathrm{Li}$ battery system. Moreover, further effort to reach theoretical capacity by full utilization of inherent $\mathrm{Na}$ ions (85\% in the present paper) can lead to energy density of $>540 \mathrm{Wh} \mathrm{kg}^{-1}$, which is higher than those of $\mathrm{LiMn}_{2} \mathrm{O}_{4}$ $\left(430 \mathrm{Wh} \mathrm{kg}^{-1}\right)$ and $\mathrm{LiFePO}_{4}\left(500 \mathrm{Wh} \mathrm{kg}^{-1}\right)$.

Complementing this electrode performance, $\mathrm{Na}_{2} \mathrm{Fe}_{2}\left(\mathrm{SO}_{4}\right)_{3}$ can be easily prepared and upscaled by low-temperature solid-state methods, although care should be taken on the hygroscopic nature. The sustainability of $\mathrm{Na}_{2} \mathrm{Fe}_{2}\left(\mathrm{SO}_{4}\right)_{3}$ further arises from its economic $\mathrm{Na}-\mathrm{Fe}-\mathrm{S}-\mathrm{O}$ elemental constitution. In earth's upper crust, $\mathrm{Na}$ and $\mathrm{Fe}$ are the most abundant and geographically distributed alkali and $3 d$ transition metal, respectively. Talking about sulphur and sulphate compounds, they are very economic and widely used in fertilizers, pesticides and chemical industries. In fact, they are extremely cheap, being a byproduct of fuel combustion, coal power plants and oil/petrochemical industries. Thus, $\mathrm{Na}_{2} \mathrm{Fe}_{2}\left(\mathrm{SO}_{4}\right)_{3}$ form an ideal material for economic production and large-scale battery manufacturing. We strongly believe that $\mathrm{Na}_{2} \mathrm{Fe}_{2}\left(\mathrm{SO}_{4}\right)_{3}$ cathode will not only open up a new sub-group of polyanionic cathodes with commercial potential, but also inspire future success in discovering superior electrode materials for next-generation secondary batteries.

\section{Methods}

Synthesis. The target material was synthesized by reacting $1.54 \mathrm{~g} \mathrm{Na}_{2} \mathrm{SO}_{4}$ (Wako, 99\%) and $2.73 \mathrm{~g} \mathrm{FeSO}_{4}$. The anhydrous $\mathrm{FeSO}_{4}$ precursor was prepared in-house by annealing commercial $\mathrm{FeSO}_{4} .7 \mathrm{H}_{2} \mathrm{O}$ (Wako, 99\%) under vacuum at $200{ }^{\circ} \mathrm{C}$ for $12 \mathrm{~h}$ (ref. 35). $\mathrm{Na}_{2} \mathrm{Fe}_{2}\left(\mathrm{SO}_{4}\right)_{3}$ cathode compound was obtained via classical solid-state synthesis by ball milling the precursors for $4 \mathrm{~h}$ followed by annealing the mixture at $350^{\circ} \mathrm{C}$ for $24 \mathrm{~h}$ under steady Ar flow. As $\mathrm{SO}_{4}$-based compounds are prone to dissolvation (in water) and thermal decomposition, we used these sustainable nonaqueous, low-temperature methods. Chemical oxidation was performed to obtain desodiated $\mathrm{Na}_{2}-{ }_{x} \mathrm{Fe}_{2}\left(\mathrm{SO}_{4}\right)_{3}$ samples using $\mathrm{NO}_{2} \mathrm{BF}_{4}$ (Alfa Aesar, 96\%) oxidant dissolved in acetonitrile solvent (Wako, $\mathrm{H}_{2} \mathrm{O}$ level $<5$ p.p.m.). The solution was stirred overnight (with steady Ar flow), and the final products were filtered and dried at $60^{\circ} \mathrm{C}$ under vacuum.

Material characterization. X-ray powder diffraction patterns were acquired in the $2 \theta$ range of $10-80^{\circ}$ by a Bruker AXS D8 ADVANCE powder diffractometer equipped with a Co $\mathrm{K} \alpha$ radiation source operating at $35 \mathrm{kV}$ and $40 \mathrm{~mA}$. Synchrotron powder XRD data for Rietveld refinement was obtained under vacuum at the BL- $4 \mathrm{~B}_{2}$ beam line of Photon Factory (PF), High Energy Accelerator Research Organization (KEK), Tsukuba, Japan. The wavelength was calibrated to be $1.196179(10) \AA$ A. For all the XRD measurements, samples were mounted on an airtightened custom-designed sample holder, which was covered with polyimide film inside an Ar-filled glove box to avoid any undesirable influence of air exposure. The determination of the peak positions and indexing were carried out with TOPASAcademic Ver. 4.1 programme. The structure of $\mathrm{Na}_{2} \mathrm{Fe}_{2}\left(\mathrm{SO}_{4}\right)_{3}$ was solved by the parallel tempering algorithm ${ }^{37}$ available in the global optimization programme $\mathrm{FOX}^{38}$, where tetrahedral constraints are applied to $\mathrm{SO}_{4}$ units. The positions and occupancies were refined by subsequent Rietveld refinement using TOPASAcademic Ver.5 programme, and the final structure was illustrated with VESTA software ${ }^{39}$. The BVS for $\mathrm{Na}$ is calculated for whole space in the unit cell of $\mathrm{Na}_{2} \mathrm{Fe}_{2}\left(\mathrm{SO}_{4}\right)_{3}$ within a grid resolution of $0.1 \AA$. The modified 'soft-BV' parameters are used by utilizing an expanded evaluation range of the bonding interaction; $r_{0}=1.5602$ and $B=0.483$ for $\mathrm{Na}-\mathrm{O}$ bond $^{28}$. The penalty term of asymmetric coordinate was neglected. The Mössbauer spectra were taken with a Topologic System Inc. spectrometer with a ${ }^{57} \mathrm{Co} \gamma$-ray source, calibrated with $\alpha$-Fe as standard. The model fitting was performed with MossWinn 3.0 software. Particle morphology of powder samples was analysed by a Hitachi S-4800 field-emission scanning electron microscope operating at $2 \mathrm{kV}$.

Electrochemical characterization. For electrochemical measurements, the working electrode was formulated by mixing $80 \mathrm{wt} \% \mathrm{Na}_{2} \mathrm{Fe}_{2}\left(\mathrm{SO}_{4}\right)_{3}$ active material, 
$15 \mathrm{wt} \%$ carbon black (Ketjen Black ECP, Lion Corp.) and $5 \mathrm{wt} \%$ polytetrafluoroethylene binder. This working electrode tape was pressed on an Ti mesh working as the current collector, with an average cathode loading of ca. $3 \mathrm{mg} \mathrm{cm}^{-2}$. Beakertype three-electrode cells were assembled inside an Ar-filled glove box by taking the cathode film as the working electrode and $\mathrm{Na}$ metal foils acting as counter and reference electrodes. These beaker cells were filled with $1 \mathrm{M} \mathrm{NaClO}_{4}$ dissolved in propylene carbonate acting as electrolyte with no additives. Galvanostatic chargedischarge cycling was conducted in the voltage ranges, $2.0-4.5 \mathrm{~V}$, at different rates from C/20 to $20 \mathrm{C}$ (at $25^{\circ} \mathrm{C}$ ). Rate capability tests were carried out using 2032-type coin cells with $\mathrm{Na}$ metal anode. Composite positive electrodes of $85 \mathrm{wt} \%$ active materials, $10 \mathrm{wt} \% \mathrm{ECP}$ and $5 \mathrm{wt} \%$ polyvinylidene fluoride were mixed in $\mathrm{N}$-methylpyrrolidone. The slurry was uniformly casted on an $\mathrm{Al}$ foil with an average loading of $c a .1 \mathrm{mg} \mathrm{cm}^{-2}$, and dried at $120^{\circ} \mathrm{C}$ under vacuum. The electrolyte solution was $1.0 \mathrm{~mol} \mathrm{dm}^{-3} \mathrm{NaPF}_{6}$ dissolved in a mixture of ethylene carbonate:diethyl carbonate (5:5 by vol., Kishida Chemical) with 2 vol\% of fluorinated ethylene carbonate (Kishida Chemical) as an electrolyte additive ${ }^{40}$. A glass fibre filter (GB-1000R, ADVANTEC) was used as a separator. The coin cells were discharged to $1.5 \mathrm{~V}$ at different rate from $\mathrm{C} / 20$ to $20 \mathrm{C}$. Before each discharge, the cells were charged at $\mathrm{C} / 20$ to $4.2 \mathrm{~V}$.

In situ XRD. In situ XRD measurements were conducted on BL-3A at KEK-PF using synchrotron radiation $(\lambda=0.12 \mathrm{~nm})$ at room temperature. Diffraction data (exposure time, $30 \mathrm{~s}$ ) were collected with reflection geometry by a two-dimensional detector (PILATUS-100K, DECTRIS). As an electrode, $80 \mathrm{wt} \% \mathrm{Na}_{2} \mathrm{Fe}_{2}\left(\mathrm{SO}_{4}\right)_{3}$, $10 \mathrm{wt} \% \mathrm{ECP}$ and $10 \mathrm{wt} \%$ polytetrafluoro-ethylene binder were mixed, pressed onto a $10 \mu \mathrm{m} \mathrm{Al}$ foil and dried at $120^{\circ} \mathrm{C}$ under vacuum. An in situ XRD cell (RIGAKU) filled with $1 \mathrm{M} \mathrm{NaClO}_{4}$ dissolved propylene carbonate electrolyte was assembled in the following order: Be window, $\mathrm{Na}_{2} \mathrm{Fe}_{2}\left(\mathrm{SO}_{4}\right)_{3}$ pellet on $\mathrm{Al}$ foil, a glass fibre filter and $\mathrm{Na}$ metal. The cell was cycled in the voltage range of $2-4.2 \mathrm{~V}$ at $\mathrm{C} / 5$ current rate (at $25^{\circ} \mathrm{C}$ ).

Computation methods. All the density functional theory (DFT) calculations were performed with the Vienna $a b$ initio simulation package VASP ${ }^{41}$. The projector augmented wave method ${ }^{42}$ as implemented in the VASP code was used. The generalized gradient approximation (GGA) $\left(\mathrm{PBE}^{43}\right)$ exchange-correlation functional was assumed, this eliminated the contribution of polaron transport in the migration calculations when the GGA $+U$ method was used and allowed comparison with literature values. Spin-polarized calculations assuming ferromagnetic orderings of the $\mathrm{Fe}$ ions were conducted. A cutoff of $520 \mathrm{eV}$ for the planewave expansion was used. The integration in the reciprocal space was conducted at the $\Gamma$ point. Both Na poor and rich regions were investigated and was modelled with a $1 \times 1 \times 2$ supercell that has a formula of $\mathrm{Na}_{1} \mathrm{Fe}_{16} \mathrm{~S}_{24} \mathrm{O}_{96}$ per unit cell containing 137 atoms. The activation energy for $\mathrm{Na}^{+}$migration was calculated with the climbing nudged elastic band ${ }^{44}$ method. The unit cell dimensions were fixed at the optimized unit cell size of this concentration during the nudged elastic band runs, otherwise all the ions were allowed to relax. Convergence of the forces were set to $0.015 \mathrm{eV}^{-1}$ and the equilibrium pressure was smaller than $|0.5|$ kbar.

\section{References}

1. Mizushima, K., Jones, P. C., Wiseman, P. J. \& Goodenough, J. B. $\mathrm{Li}_{\mathrm{x}} \mathrm{CoO}_{2}$ $(0<\mathrm{x}<1)$ : A new cathode material for batteries of high energy density. Mater. Res. Bull. 15, 783-789 (1980).

2. Thackeray, M. M., David, W. I. F., Bruce, P. G. \& Goodenough, J. B. Lithium insertion into manganese spinels. Mater. Res. Bull. 18, 461-472 (1983).

3. Padhi, A. K., Nanjundaswamy, K. S. \& Goodenough, J. B. Phospho-olivines as positive-electrode materials for rechargeable lithium batteries. J. Electrochem. Soc. 144, 1188-1194 (1997).

4. Tarascon, J. M. Is lithium the new gold? Nat. Chem. 2, 510 (2010).

5. Delmas, C., Braconnier, J. J., Fouassier, C. \& Hagenmuller, P. Electrochemical insertion of sodium in $\mathrm{Na}_{\mathrm{x}} \mathrm{CoO}_{2}$ bronzes. Solid State Ion 3-4, 165-169 (1981).

6. Komaba, S. et al. Electrochemical $\mathrm{Na}$ insertion and solid electrolyte interphase for hard-carbon electrodes and application to Na-ion batteries. Adv. Funct. Mater. 21, 3859-3867 (2011).

7. Yabuuchi, N. et al. P2-type $\mathrm{Na}_{\mathrm{x}}\left[\mathrm{Fe}_{1 / 2} \mathrm{Mn}_{1 / 2}\right] \mathrm{O}_{2}$ made from earth-abundant elements for rechargeable Na batteries. Nat. Mater. 11, 512-517 (2012).

8. Ellis, B. L., Makahnouk, W. R. M., Makimura, Y., Toghill, K. \& Nazar, L. F. A multifunctional $3.5 \mathrm{~V}$ iron-based phosphate cathode for rechargeable batteries. Nat. Mater. 6, 749-753 (2007).

9. Moreau, P., Guyomard, D., Gaubicher, J. \& Boucher, F. Structure and stability of sodium intercalated phases in olivine $\mathrm{FePO}_{4}$. Chem. Mater. 22, 4126-4128 (2010).

10. Barpanda, P. et al. Sodium iron pyrophosphate: A novel $3.0 \mathrm{~V}$ iron-based cathode for sodium-ion batteries. Electrochem. Commun. 24, 116-119 (2012).

11. Kim, H. et al. New iron-based mixed-polyanion cathodes for lithium and sodium rechargeable batteries: combined first principles calculations and experimental study. J. Am. Chem. Soc. 134, 10369-10372 (2012).

12. Whittingham, M. S. Electrical energy storage and intercalation chemistry. Science 192, 1126-1127 (1976).
13. Okada, S. et al. Layered transition metal oxides as cathodes for sodium secondary battery. ECS Meeting Abstract MA2006-02, 201 (2006).

14. Padhi, A. K., Nanjundaswamy, K. S., Masquelier, C. \& Goodenough, J. B. Mapping of transition metal redox energies in phosphates with NASICON structure by lithium intercalation. J. Electrochem. Soc. 144, 2581-2586 (1997).

15. Barpanda, P. et al. Structural, transport, and electrochemical investigation of novel $\mathrm{AMSO}_{4} \mathrm{~F}(\mathrm{~A}=\mathrm{Na}, \mathrm{Li} ; \mathrm{M}=\mathrm{Fe}, \mathrm{Co}, \mathrm{Ni}, \mathrm{Mn})$ metal fluorosulphates prepared using low temperature synthesis routes. Inorg. Chem. 49, 7401-7413 (2010).

16. Ati, M. et al. Synthesis, structural, and transport properties of novel bihydrated fluorosulphates $\mathrm{NaMSO}_{4} \mathrm{~F} \cdot 2 \mathrm{H}_{2} \mathrm{O}(\mathrm{M}=\mathrm{Fe}, \mathrm{Co}$, and $\mathrm{Ni})$. Chem. Mater. 22, 4062-4068 (2010).

17. Trad, K. et al. $\mathrm{NaMnFe}{ }_{2}\left(\mathrm{PO}_{4}\right)_{3}$ alluaudite phase: synthesis, structure, and electrochemical properties as positive electrode in lithium and sodium batteries. Chem. Mater. 22, 5554-5562 (2010).

18. Manthiram, A. \& Goodenough, J. B. Lithium insertion into $\mathrm{Fe}_{2}\left(\mathrm{SO}_{4}\right)_{3}$ frameworks. J. Power Sources. 26, 403-408 (1989).

19. Okada, S., Arai, S. \& Yamaki, J. Iron complex cathodes. Denki Kagaku 65, 802-808 (1997).

20. Chung, S. C., Barpanda, P., Nishimura, S., Yamada, Y. \& Yamada, A. Polymorphs of $\mathrm{LiFeSO}_{4} \mathrm{~F}$ as cathode materials for lithium ion batteries - a first principle computational study. Phys. Chem. Chem. Phys. 14, 8678-8682 (2012).

21. Barpanda, P. et al. A 3.90V iron-based fluorosulphate material for lithium-ion batteries crystallizing in the triplite structure. Nat. Mater. 10, 772-779 (2011)

22. Nishimura, S., Nakamura, M., Natsui, R. \& Yamada, A. New lithium iron pyrophosphate as $3.5 \mathrm{~V}$ class cathode material for lithium ion battery. J. Am. Chem. Soc. 132, 13596-13597 (2010).

23. Reynaud, M. et al. $\mathrm{Li}_{2} \mathrm{Fe}\left(\mathrm{SO}_{4}\right)_{2}$ as a $3.83 \mathrm{~V}$ positive electrode material. Electrochem. Commun. 21, 77-80 (2012).

24. Ye, T. et al. General observation of $\mathrm{Fe}^{3+} / \mathrm{Fe}^{2+}$ redox couple close to $4 \mathrm{~V}$ in partially substituted $\mathrm{Li}_{2} \mathrm{FeP}_{2} \mathrm{O}_{7}$ pyrophosphate solid-solution cathodes. Chem. Mater. 25, 3623-3629 (2013).

25. Yamada, A. et al. Room-temperature miscibility gap in $\mathrm{Li}_{\mathrm{x}} \mathrm{FePO}_{4}$. Nat. Mater 5, 357-360 (2006).

26. Wang, Y. et al. A zero-strain layered metal oxide as the negative electrode for long-life sodium-ion batteries. Nat. Commun. 4, 2365 (2013).

27. Lu, J., Chung, S. C., Nishimura, S. \& Yamada, A. Phase diagram of olivine $\mathrm{Na}_{\mathrm{x}} \mathrm{FePO}_{4}$. Chem. Mater. 25, 3623-3629 (2013).

28. Brown, I. D. IUCr Monographs on Crystallography 12 (Oxford University Press, 2002).

29. Adam, S. Relationship between bond valence and bond softness of alkali halides and chalcogenides. Acta Cryst. B57, 278-287 (2001).

30. Adam, S. From bond valence maps to energy landscapes for mobile ions in ionconducting solids. Solid State Ion 177, 1625-1630 (2006).

31. Ong, S. P. et al. Voltage, stability and diffusion barrier differences between sodium-ion and lithium-ion intercalation materials. Energy Environ. Sci. 4, 3680-3688 (2011).

32. Clark, J. M. et al. High-voltage pyrophosphate cathode: insights into local structure and lithium diffusion pathways. Angew. Chem. Int. Ed. 51, 13149-13153 (2012).

33. Kim, H. et al. $\mathrm{Na}_{2} \mathrm{FeP}_{2} \mathrm{O}_{7}$ as a promising iron-based pyrophosphate cathode for sodium rechargeable batteries: a Combined Experimental and Theoretical Study. Adv. Funct. Mater. 23, 1147-1155 (2013).

34. Nishimura, S. et al. Experimental visualization of lithium diffusion in $\mathrm{Li}_{\mathrm{x}} \mathrm{FePO}_{4}$ Nat. Mater. 7, 707-711 (2008).

35. Malik, R. et al. Particle size dependence of the ionic diffusivity. Nano Lett. 10, 4123-4127 (2010).

36. Subban, C. V. et al. Preparation, structure, and electrochemistry of layered polyanionic hydroxysulfates: $\mathrm{LiMSO}_{4} \mathrm{OH}(\mathrm{M}=\mathrm{Fe}, \mathrm{Co}, \mathrm{Mn})$ electrodes for Li-ion batteries. J. Am. Chem. Soc. 135, 3653-3661 (2013).

37. Falcioni, M. \& Deem, M. W. A biased Monte Carlo scheme for zeolite structure solution. J. Chem. Phys. 110, 1754-1766 (1999).

38. Favre-Nicolin, V. \& Cerny, R. FOX, 'free objects for crystallography': a modular approach to $a b$ initio structure determination from powder diffraction. J. Appl. Cryst. 35, 734-743 (2002).

39. Momma, K. \& Izumi, F. VESTA 3 for three-dimensional visualization of crystal volumetric and morphology data. J. Appl. Cryst. 44, 1272-1276 (2011).

40. Komaba, S. et al. Fluorinated ethylene carbonate as electrolyte additive for rechargeable Na batteries. ACS Appl. Mater. Interfaces 3, 4165-4168 (2011).

41. Kresse, G. \& Furthmüller, J. Efficiency of ab-initio total energy calculations for metals and semiconductors using a plane-wave basis set. Comput. Mater. Sci. 6, 15-50 (1996)

42. Blöchl, P. E. Projector augmented-wave method. Phys. Rev. B 50, 17953-17979 (1994).

43. Perdew, J. P., Burke, K. \& Ernzerhof, M. Generalized gradient approximation made simple. Phys. Rev. Lett. 77, 3865-3869 (1996).

44. Henkelman, G., Uberuaga, B. P. \& Jónsson, H. A climbing image nudged elastic band method for finding saddle points and minimum energy paths. J. Chem. Phys. 113, 9901-9904 (2000). 


\section{Acknowledgements}

We acknowledge the financial support from the Ministry of Education, Culture, Sports, Science and Technology, Japan (MEXT) under the 'Element Strategy Initiative for Catalysts and Batteries' (ESICB) project. P.B. is thankful to the Japan Society for the Promotion of Sciences for a JSPS Fellowship. Research Center for Computational Science, Okazaki, Japan is thanked for the computer time. The synchrotron XRD experiments were performed under KEK-PF under programme no. $2013 \mathrm{G} 670$.

\section{Author contributions}

G.O. carried out most of the experimental work on synthesis, structural, physical and electrochemical characterization following some initial work by P.B.; S.N. conducted all crystal structure and diffraction pattern analyses; and S.-C.C. performed the theoretical calculation. The ideas and experiments were conceived, analysed and planned by all co-authors led by A.Y. The manuscript was written by all authors under the supervision of A.Y.

\section{Additional information}

Supplementary Information accompanies this paper at http://www.nature.com/ naturecommunications

Competing financial interests: The authors declare no competing financial interests.

Reprints and permissions information is available online at http://npg.nature.com/ reprintsandpermissions/

How to cite this article: Barpanda, P. et al. A 3.8-V earth-abundant sodium battery electrode. Nat. Commun. 5:4358 doi: 10.1038/ncomms5358 (2014).

(c) (i) This work is licensed under a Creative Commons Attribution 4.0 International License. The images or other third party material in this article are included in the article's Creative Commons license, unless indicated otherwise in the credit line; if the material is not included under the Creative Commons license, users will need to obtain permission from the license holder to reproduce the material. To view a copy of this license, visit http://creativecommons.org/licenses/by/4.0/ 